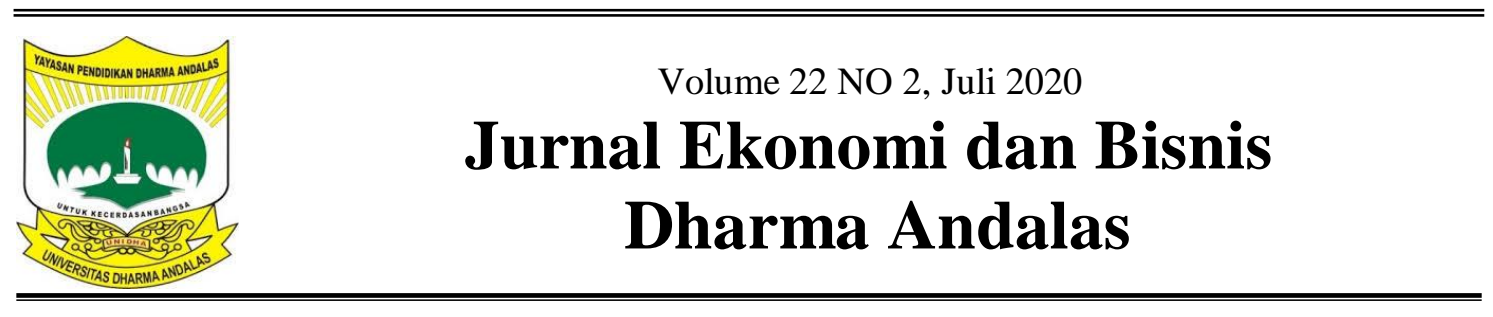

\title{
Pengaruh Loan To Deposit Ratio (LDR) dan Debt To Equity Ratio (DER) Terhadap Return On Equity (ROE) Pada Bank BNI Tbk
}

\author{
Nurul Wahyuti ${ }^{1}$, Aliah Pratiwi ${ }^{2}$ \\ ${ }^{1}$ Sekolah Tinggi Ilmu Ekonomi (STIE) Bima ${ }^{1,2}$ \\ email:nurulwahyutii@gmail.com ${ }^{1}$ \\ aliahpratiwi@ymail.com ${ }^{2}$
}

\begin{abstract}
This study aims to determine and analyze the effect of LDR and DER on ROE at PT. Bank BNI Tbk both partially and simultaneously. The type of research used is associative, with the research sample being the last 10 years financial statements namely from 2009 to 2018. The sampling technique used was purposive sampling. Data collection using financial statements at PT. Bank BNI Tbk. Data analysis methods used are multiple regression, multiple correlation, classic assumption test, $t$ test (partial) and F test (simultaneous) using the SPSS program. The results of this study concluded that the LDR has no partial effect on ROE as evidenced by the $t$ test value of 0.921 and Sig 0.388. While DER has no effect on ROE partially with a t test value of 0.407 and Sig 0.696. Furthermore, LDR and DER do not have an effect on ROE simultaneously with $F$ test values of 0.427 and Sig 0.668 .
\end{abstract}

Keywords: Loan To Deposit Ratio (LDR), Debt To Equity Ratio (DER), Return On Equity (ROE)
ABSTRAK
Penelitian ini bertujuan untuk mengetahui dan menganalisis pengaruh LDR dan DER terhadap ROE pada PT. Bank BNI Tbk baik secara parsial maupun secara simultan. Jenis penelitian yang digunakan adalah asosiatif, dengan sampel penelitian adalah laporan keuangan 10tahun terakhir yaitu dari tahun 2009 sampai tahun 2018. Teknik sampling yang digunakanadalah purposive sampling.Pengumpulan data menggunakan laporan keuangan pada PT. Bank BNI Tbk.Metode analisis data yang digunakan adalah regresi berganda, korelasi berganda, uji asumsi klasik, uji t (parsial) dan uji $\mathrm{F}$ (simultan) dengan menggunakan program SPSS.Hasil dari penelitian ini menyimpulkan bahwa LDR tidak memiliki pengaruh terhadap ROEsecara parsial yang dibuktikan dengan nilai uji tsebesar 0,921 dan Sig 0,388. Sedangkan DER tidak mempunyai pengaruh terhadap ROEsecara parsial dengan nilai uji t sebesar 0,407 dan Sig 0,696. Selanjutnya LDR dan DER tidak mempunyai pengaruh terhadap ROE secara simultan dengan nilai uji F sebesar 0,427 dan Sig 0,668.
Kata Kunci : Loan To Deposit Ratio (LDR), Debt To Equity Ratio (DER), Return On Equity (ROE)

\section{PENDAHULUAN}
Bank merupakan suatu lembaga keuangan yang berfungsi sebagai penyalur dana dari pihak yang mempunyai dana yang kelebihan dengan
pihak yang kekurangan dana atau membutuhkan dana. Bank diharapkan mampu melakukan perputaran dana tabungan masyarakat guna meningkatkan industri perbankan di 
Indonesia. Namun dalam perkembangannya, industri perbankan di Indonesia telah mengalami pasang surut.

Dunia perbankan di Indonesia memasuki masa persaingan yang sangat kompetitif, hal ini disebabkan banyaknya bank yang beroperasi di Indonesia baik yang beroperasi secara lokal maupun yang beroperasi berskala internasional.

Perkembangan dunia perbankan yang sangat pesat serta tingkat kompleksitas usaha perbankan yang tinggi dapat berpengaruh terhadap kinerja keuangan suatu bank. Lemahnya kondisi internal bank seperti manajemen yang kurang memadai, pemberian kredit kepada kelompok atau group usaha sendiri serta modal yang tidak dapat mengcover terhadap risiko-risiko yang dihadapi oleh bank tersebut dapat menyebabkan kinerja bank menurun.Ukuran kinerja keuangan berdasarkan SK Men.Keu. Nomor KEP.792/MK/IV/12/1970 tanggal 7 Desember 1970 tentang lembaga keuangan yang telah diubah dan ditambah terakhir dengan keputusan Menteri Keuangan No. 280/KMK/10/1989 tanggal 25 Maret 1989 tentang pengawasan dan pembinaan lembaga keuangan bukan bank serta ditindak lanjuti dengan Surat Edaran Bank Indonesia No. SE. 23/21/BPPP disebutkan bahwa kinerja lembaga keuangan adalah mengenai permodalan, kualitas aktiva produktif, aspek manajemen, rentabilitas, dan likuiditas.

Informasi mengenai laporan keuangan bank sebagai salah satu upaya untuk membantu para pelaku bisnis dalam menilai kondisi keuangan suatu bank. Laporan keuangan yang diterbitkan oleh bank merupakan salah satu sumber informasi mengenai posisi keuangan bank, kinerja serta perubahan posisi keuangan bank yang sangat berguna untuk menilai kinerja keuangan suatu bank. Laporan keuangan bank dapat dijadikan ukuran kinerja suatu bank dengan melakukan analisis laporan keuangan.

Untuk mengetahui besarnya profitabilitas bank, dapat diukur dengan rasio profitabilitas antara lain Return on Equity (ROE). Rasio tersebut menggambarkanbesarnya pengembalian atas total modal sendiri (saham) untuk menghasilkan keuntungan. ROE merupakan rasio antara laba sesudah pajak terhadap total ekuitas yang berasal dari setoran modal pemilik, laba tak dibagi dan cadangan lain yang dikumpulkan oleh perusahaan (Kasmir, 2016: 267).

Analisis kinerja keuangan bank dimulai dengan me-review data laporan keuangan, menghitung, membandingkan atau mengukur, menginterpretasikan dan memberi solusi. Perhitungan yang dilakukan untuk menganalisis kinerja keuangan bank dapat dilakukan dengan menggunakan berbagai teknik analisis, diantaranya adalah dengan menggunakan teknik analisis rasio. Analisis rasio merupakan analisis yang digunakan untuk mengetahui hubungan pos-pos yang ada dalam suatu laporan keuangan atau pos-pos antara laporan keuangan neraca dan laporan laba rugi (Kasmir, 2016:72). Analisis rasio keuangan merupakan teknik analisis yang sering dipakai, karena merupakan teknik yang paling cepat untuk mengetahui kinerja keuangan bank.

ROE pada perbankan dapat dipengaruhi oleh banyak faktor antara lain Loan to Deposit Ratio (LDR) dan Debt to equity ratio (DER). Loan to Deposit Ratio (LDR) merupakan salah satu indikator pengukuran likuiditas. Rasio LDR merupakan perbandingan 
antara total kredit yang diberikan dengan total Dana Pihak Ketiga (DPK) yang dapat dihimpun oleh bank (Kasmir, 2016:232). LDR akan menunjukkan tingkat kemampuan bank dalam menyalurkan dana pihak ketiga yang dihimpun oleh bank yang bersangkutan dalam hal ini Bank BNI Tbk. Kemudian dalam hal rasio solvabilitas atau rasio utang menunjukkan kemampuan perusahaan untuk memenuhi segala kewajiban finansialnya apabila sekiranya perusahaan tersebut pada saat itu dilikuidasi. Pengukuran utang digunakan rasio utang (Debt to Equity ratio), karena merupakan rasio solvabilitas dimana rasio ini ditunjukan untuk mengadakan pengukuran sampai seberapa besar modal pinjaman (utang) perusahaan yang dibandingkan dengan total equity dalam membiayai aktivitas perusahaan, dan hasil pengukuran ini dinyatakan dalam persentase dengan kata lain Debt to Equity Ratio (DER)adalah total utang dibagi total modal sendiri (Dendawijaya, 2013: 121).

Untuk mengetahui perkembangan LDR, DER dan ROE pada PT. Bank BNI Tbk selama 5 (lima) tahun terakhir maka akan disajikan dalam bentuk tabel seperti berikut ini :

Tabel 1.

\section{Data Kredit, Total Hutang dan Total Ekuitas pada PT. Bank BNI Tbk ( Dalam Jutaan Rupiah )}

\begin{tabular}{cccc}
\hline Tahun & Kredit & $\begin{array}{c}\text { Total } \\
\text { Hutang }\end{array}$ & $\begin{array}{c}\text { Total } \\
\text { ekuitas }\end{array}$ \\
\hline 2014 & 26.984 .438 & 341.148 .654 & 61.021 .308 \\
2015 & 48.482 .868 & 412.727 .677 & 78.438 .222 \\
2016 & 67.170 .243 & 492.701 .125 & 89.254 .000 \\
2017 & 57.434 .118 & 584.086 .818 & 100.903 .304 \\
2018 & 79.299 .503 & 671.237 .546 & 110.373 .789 \\
\hline
\end{tabular}

Sumber : Data Sekunder yang diolah 2020

Dari tabel diatas terlihat bahwa perkembangan nilai Kredit, Total Hutang dan Total Ekuitas pada PT. Bank BNI
Tbk mengalami kenaikan dari tahun 2014 sampai tahun 2018. Untuk nilai Kredit yang di salurkan terlihat bahwa penyaluran kredit dari tahun 2014 sampai 2018 terus mengalami peningkatan. Pada tahun 2014 nilai kredit sebesar Rp 26,9 Triliun kemudian mengalami kenaikan di tahun 2015 dan 2016 menjadi Rp 48,4 Triliun dan Rp 67,1 Triliun. Selanjutnya di tahun 2017 penyaluran kredit bank kembali mengalami peningkatan menjadi Rp 57,4 Triliun dan di tahun 2018 menjadi Rp 79,2 Triliun.

Hal yang sama juga terjadi pada nilai hutang pada PT. Bank BNI Tbk. Pada tahun 2014-2018 terus mengalami peningkatan. Dari tabel diatas dapat terlihat bahwa nilai hutang pada tahun 2014 adalah sebesar Rp 341,1 Triliun, kemudian mengalami kenaikan di tahun 2015 dan tahun 2016 menjadi Rp 412,7 Triliun dan $\mathrm{Rp}$ 492,7 Triliun. Di tahun 2017 dan 2018 kembali mengalami peningkatan hutang yang cukup signifikan yaitu sebesar Rp 584 Triliun di tahun 2017 dan Rp 671,2 Triliun di tahun 2018. Kemudian untuk nilai ekuitas pada PT. Bank BNI Tbk juga terjadi hal yang sama dengan data kredit dan data hutang.

Pada tabel 1 di atas terlihat bahwa nilai ekuitas perusahaan pada tahun 2014 sampai tahun 2018 terus mengalami peningkatan. Dari tabel diatas terliha bahwa nilai ekuitas perusahaan di tahun 2014 yaitu sebesar Rp 61 Triliun, kemudian di tahun 2015 dan di tahun 2016 juga mengalami peningkatan yaitu di tahun 2015 sebesar Rp 78,4 Triliun dan tahun 2016 sebesar Rp 89,2 Triliun. Selanjutnya di tahun 2017 dan tahun 2018 juga kembali mengalami peningkatan nilai ekuitas yang cukup signifikan yaitu Rp 100,9 
Triliun di tahun 2017 dan meningkat sebesar Rp 110,3 Triliun di tahun 2018.

Akan tetapi perkembangan diatas akan berdampak pada penggunaan modal oleh perusahaan untuk menutupi sejumlah hutang yang juga mengalami peningkatan signifikan. Selain itu jumlah kredit yang diberikan oleh pihak bank pada masyarakat terus mengalami peningkatan, hal itu juga akan berimbas pada ketersediaan modal bagi perusahaan. Sehingga secara tidak langsung juga akan berdampak pada sedikit atau banyaknya perolehan laba perusahaan.

Kemudian krisis keuangan yang dialami sejumlah negara sejak beberapa waktu terakhir ini mempengaruhi kondisi keuangan Indonesia. Krisis keuangan global merupakan sumber instabilitas yang utama, baik bagi perusahaan perbankan maupun perusahaan non perbankan. Dampak krisis ini dialami juga oleh Bank BNI Tbk, hal-hal ini dapat mendorong terjadinya peningkatan kredit bermasalah serta perlambatan pertumbuhan kredit dan pembiayaan lainnya dalam valas yang dibutuhkan untuk mendukung kegiatan perekonomian. Selain itu adanya kredit bermasalah akan mempengaruhi permodalan yang juga dapat menyebabkan bank mengalami masalah likuiditas. Pertumbuhan kredit yang belum optimal tercermin dari angka-angka Loan to Deposit Ratio (LDR) yang tinggi. Masalah lainnya yang timbul adalah nilai DER yang tidak stabil atau fluktuatif (naik turun) dapat menjadi faktor bank tidak dapat tumbuh optimal, sehingga berdampak pada tingkat pengembalian modal untuk memperoleh laba atau ROE.

Penelitian Widowati (2015) menyatakan bahwa LDR tidak berpengaruh dengan ROE itu yang membuktikan keadaan kredit bermasalah tinggi yang menurunkan kinerja bank, oleh karena itu kalau ada kredit bermasalah tinggi maka bank tidak mampu menyalurkan kredit kepada nasabah. Selanjutnya penelitian rosyadah (2012) menyatakan bahwa penggunaan hutang dengan tingkat bunga akan berpengaruh besar terhadap ROE karena semakin tingginya tingkat bunga hutang maka akan semakin tinggi beban tetap terhadap pendapatan sehingga kondisi tersebut kurang baik terhadap ROE dan begitu sebaliknya.

Berdasarkan uraian tersebut diatas, maka dilakukan penelitian untuk menganalisis sejauh mana pengaruh yang ditimbulkan Loan To Deposit Ratio (LDR) Dan Debt To Equity Ratio (DER) Terhadap Return On Equity (ROE) Pada Bank Bni Tbk.

\section{METODE PENELITIAN}

Jenis Penelitian

Dalam penelitian ini digunakan jenis penelitian Asosiatif yaitu suatu penelitian yang bersifat mengetahui hubungan antara dua variabel atau lebih dan mempunyai tingkat yang lebih bila di bandingkan dengan penelitian deskriptif dan komparatif (Sugiyono 2016).

\section{Instrumen Penelitian}

Instrumen penelitian yang digunakan yaitu data laporan keuangan Bank BNI Tbk berupa laporan Neraca dan Laba/rugi yang dapat diakses pada www.bni.co.id atau laporan keuangan yang terdaftar di Bursa Efek Indonesia dapat diakses pada www.idx.co.id

Populasi Dan Sampel Penelitian

Populasi yang digunakan yaitu laporan keuangan Bank BNI Tbk sejak pertama berdiri tahun 1946 sampai sekarang tahun 2018. 
Sampel yang digunakan dalam penelitian adalah laporan keuangan Bank BNI Tbk (go public) selama 10 tahun terakhir dari tahun 2009 sampai tahun 2018.

Teknik sampling yang digunakan adalah sampling purposive, yaitu pengambilan sampel berdasarkan pertimbangan peneliti dimana sampel selama 10 tahun terakhir dianggap sudah sangat baik dan valid serta tercatat dalam BEI.

Teknik Pengumpulan Data

Teknik pengumpulan data yang digunakan yaitu (1) Dokumentasi, (2) Studi pustaka

\section{Jenis Dan Sumber Data}

Jenis Data yang digunakan dalam penelitian ini adalah data kuantitatif yaitu data yang dapat dihitung atau diukur dengan angka, dalam hal ini data laporan keuangan pada PT. Bank BNI Tbk.

Sumber Data dalam penelitian ini adalah sekunder yaitu data yang diperoleh secara tidak langsung melalui website PT. BNI Tbk atau literatur yang menunjang penelitian ini.

Teknik Analisa Data

Dalam penelitian ini teknik analisis data yang digunakan antara lain :

(1) Uji asumsi klasik. Uji asumsi klasik adalah analisis yang dilakukan untuk menilai apakah di dalam sebuah model regresi linear Ordinary Least Square (OLS) terdapat masalah-masalah asumsi klasik

(2) Regresi linier berganda. Regresi linier berganda adalah didasarkan pada hubungan fungsional ataupun kausal dua atau lebih variabel independen dengan satu variabel dependen (Sugiyono, 2016 :224)

(3) Koefisien korelasi berganda. Koefisien korelasi berganda merupakan angka yang menunjukkan arah dan kuatnya hubungan antara dua variabel independen secara bersama-sama atau lebih dengan satu variabel dependen (Sugiyono, $2016: 230$ )

(4) Uji t. Uji t adalah pengujian signifikansi pengaruh secara parsial yaitu apakah pengaruh ditemukan untuk semua populasi (Sugiyono, 2016: 236)

(5) Uji F. Uji F yaitu uji untuk melihat bagaimanakah pengaruh semua variabel bebasnya secara bersama-sama terhadap variabel terikatnya dan atau untuk menguji apakah model regresi yang kita buat signifikan atau tidak signifikan

\section{HASIL DAN PEMBAHASAN}

Uji Asumsi Klasik

Uji Normalitas

Pengujian kenormalan terrhadap residual regresi dua variabel bebas terhadap variabel terikat dapat dilihat pada tabel One-Sample KolmogogrovSmirnov Test berikut ini :

Tabel 2

\section{Hasil Uji Normalitas One-Sample Kolmogorov-Smirnov Test \\ One-Sample Kolmogorov-Smirnov Test}

\begin{tabular}{llr}
\hline & & $\begin{array}{r}\text { Unstandardized } \\
\text { Predicted Value }\end{array}$ \\
\hline $\mathrm{N}$ & Mean & 10 \\
Normal & Std. & 14,5410000 \\
Parameters $\mathrm{a}, \mathrm{b}$ & Deviation &, 80530821 \\
& Absolute &, 108 \\
Most Extreme & Positive &, 108 \\
Differences & Negative &,- 085 \\
Kolmogorov-Smirnov Z &, 342 \\
\hline \multicolumn{2}{l}{ Asymp. Sig. (2-tailed) } & 1,000 \\
\hline a. Test distribution is Normal.
\end{tabular}

b. Calculated from data.

Berdasarkan tabel diatas diperoleh nilai Asymp. Sig. (2-tailed) sebesar 1,000 dan nilai ini lebih besar dari $0,05(1,000>0,05)$ artinya data pada penelitian ini berdistrbusi normal.

Sesuai syarat dan ketentuan, dimana :

Jika nilai Asymp. Sig. $(2-$ tailed $)$

$\geq 0,05$ maka data berdistribusi normal 
Jika nilai Asymp. Sig. (2 - tailed $)$ $<0,05$ maka data tidak berdistribusi normal.

Uji Multikolinearitas

Menurut Ghozali (2011:112) Uji Multikolonieritas bertujuan untuk menguji apakah model regresi ditemukan adanya korelasi atar variabel bebas (Independen). Model korelasi yang baik seharusnya tidak terjadi korelasi di antara variabel independen.Jika variabel independen saling berkorelasi maka variabel ini tidak ontogonal. Variebel ontogonal adalah variabel independen yang nilai korelasi antar sesama variabel independen sama dengan nol.

Ketentuan :

Tolerance value $<0,10$ atau VIF > 10 maka terjadi multikolenearitas

Tolerance value $>0,10$ atau VIF $<10$ maka tidak terjadi multikolenearitas

Tabel 3

Hasil Uji Multikolinearitas Coefficients $^{a}$

\begin{tabular}{|c|c|c|c|}
\hline \multirow[t]{2}{*}{ Mod } & & \multicolumn{2}{|c|}{ Collinearity Statistics } \\
\hline & & Tolerance & VIF \\
\hline \multirow{3}{*}{1} & (Con & & \\
\hline & LDR & 729 & 1,372 \\
\hline & DER & ,729 & 1,372 \\
\hline
\end{tabular}

diperoleh nilai tolerance untuk variabel LDR dan DER sebesar 0,729>0,10 dan VIF sebesar $1,372<10$ maka dapat disimpulkan tidak terjadi multikolinearitas

Uji Heteroskedastisitas

Menurut Ghozali (2011:112) Uji heterokedastitas bertujuan untuk menguji apakah dalam model regresi terjadi ketidaksamaan variance dari residual satu pengamatan ke pengamatan lainnya. Penelitian ini menggunakakan uji scater plot.

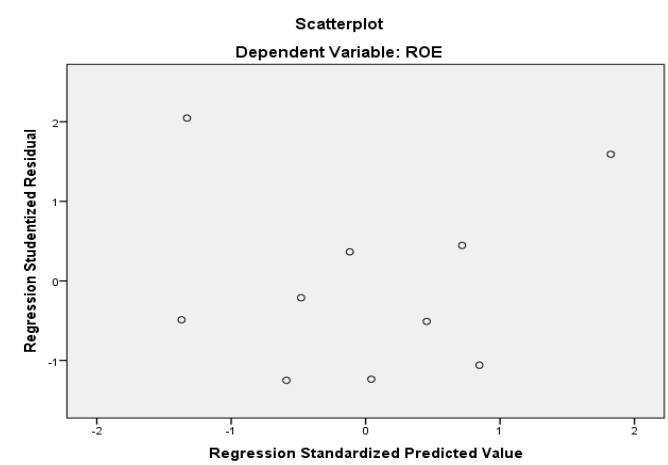

Gambar 1

Hasil Uji Heteroskedastisitas

Dari hasil uji SPSS ditemukan bahwa data dalam penelitian tidak terjadi heteroskedastisitas. Hal ini terlihat pada uji scatterplot dimana sebaran titik-titik tidak membentuk pola tertentu. Sehingga data dapat dikatakan tidak terjadi heteroskedastisitas.

Uji Autokorelasi

Uji autokorelasi bertujuan untuk menguji apakah dalam suatu model regresi linear ada korelasi antara kesalahan pengganggu pada periode $\mathrm{t}$ dengan kesalahan pada periode t-1 (sebelumnya). Cara untuk mendeteksi ada tidaknya autokorelasi dalam suatu data time series dapat menggunakan Uji Durbin Watson.Uji Durbin Watson ini hanya digunakan untuk autokorelasi tingkat satu dan mensyaratkan adanya intersep dalam model regresi dan tidak ada variabel lagi diantara variabel penjelas.

Di dalam uji Durbin Watson ini, harus meenuhi kriteria sebagai berikut :

Tabel 4

Pedoman Kriteria Durbin Watson

\begin{tabular}{cc}
\hline Kriteria Durbin Watson & Keterangan \\
\hline $1,65<\mathrm{DW}<2,35$ & Tidak terjadi autokorelasi \\
$1,21<\mathrm{DW}<1,65$ & Tidak dapat disimpulkan \\
$2,35<\mathrm{DW}<2,79$ & Tidak dapat disimpulkan \\
$\mathrm{DW}<1,21$ & Terjadi autokorelasi \\
$\mathrm{DW}>2,79$ & Terjadi autokorelasi \\
\hline
\end{tabular}

Sumber : Sulaiman, 2004

Dari hasil olah data SPSS maka

diperoleh nilai durbin watson sebesar 
1,818. Nilai Durbin Watson ini memenuhi kriteria 1,65 < DW $<2,35$ yang artinya tidak terjadi autokorelasi.

\section{$1,65<1,818<2,35$}

Untuk lebih jelasnya nilai Durbin Watson dapat dilihat dari tabel olah data SPSS berikut :

\begin{tabular}{lc} 
& Tabel 5 \\
& \multicolumn{1}{c}{$\begin{array}{c}\text { Hasil Uji Durbin Watson } \\
\text { Model Summary }\end{array}$} \\
\hline Model & Durbin-Watson \\
\hline 1 & 1,373 \\
\hline $\begin{array}{l}\text { a. Predictors: (Constant), DER, LDR } \\
\text { b. Dependent Variable: ROE }\end{array}$
\end{tabular}

Regresi Linier Berganda

Tabel 6

Hasil Regresi Linier Berganda Coefficients $^{\mathrm{a}}$

\begin{tabular}{rlrr}
\hline Model & \multicolumn{2}{c}{ Unstandardized Coefficients } \\
\cline { 3 - 4 } & & \multicolumn{1}{c}{ B } & \multicolumn{1}{c}{ Std. Error } \\
\hline \multirow{2}{*}{1} & (Constant) & 9,738 & 6,649 \\
& LDR &, 257 &, 280 \\
& DER &, 003 &, 006 \\
\hline
\end{tabular}

a. Dependent Variable: ROE

Dari hasil olah data diatas dengan SPSS maka dapat dimasukkan dalam persamaan regresi linier berganda sebagai berikut :

$$
\begin{aligned}
& Y=a+b_{1} X_{1}+b_{2} X_{2} \\
& Y=9,738+0,257 X_{1}+0,003 X_{2}
\end{aligned}
$$

Dari persamaan regresi berganda tersebut dapat dijelaskan bahwa :

$\mathrm{Y}$ : nilai variabel ROE

a : Konstanta atau bila harga $\mathrm{X}_{1}$ dan $\mathrm{X}_{2}$ $=0$ maka nilai variabel $\mathrm{ROE}$ adalah sebesar 9,738 kali

$b_{1}$ : Koefisien regresi LDR, bila dinaikkan sebesar 1 kriteria maka ROE akan mengalami kenaikan sebesar 0,257 kali

$\mathrm{b}_{2}$ : Koefisien regresi DER, bila dinaikkan sebesar 1 kriteria maka ROE akan mengalami kenaikan sebesar 0,003 kali

Koefisien Korelasi
Dari hasil olah data SPSS maka diperoleh nilai untuk korelasi berganda sebesar 0,330

Tabel 7

Hasil Korelasi Berganda

\begin{tabular}{lccccc}
\multicolumn{6}{c}{ Model Summary $^{\mathrm{b}}$} \\
\hline Model & $\mathrm{R}$ & $\begin{array}{c}\mathrm{R} \\
\text { Square }\end{array}$ & $\begin{array}{c}\text { Adjusted R } \\
\text { Square }\end{array}$ & $\begin{array}{c}\text { Std. Error of } \\
\text { the Estimate }\end{array}$ & $\begin{array}{r}\text { Durbin- } \\
\text { Watson }\end{array}$ \\
\hline 1 &, $330^{\mathrm{a}}$ &, 109 &, 146 & 2,61327 & 1,373 \\
\hline \multicolumn{7}{l}{ a. Predictors: (Constant), DER, LDR } \\
\end{tabular}

Untuk dapat memberi interpretasi terhadap kuatnya pengaruh itu maka dapat digunakan pedoman seperti tabel berikut :

Tabel 8

Pedoman Koefisien Korelasi

\begin{tabular}{cc}
\hline Interval Koofisien & Tingkat Pengaruh \\
\hline $0,00-0,199$ & Sangat Rendah \\
$0,20-0,399$ & Rendah \\
$0,40-0,599$ & Sedang \\
$0,60-0,799$ & Kuat \\
$0,80-1,000$ & Sangat Kuat \\
\hline
\end{tabular}

Sumber : Sugiyono, 2016

Jadi pengaruh kualitas produk dan kualitas pelayanan terhadap loyalitas konsumen sebesar 0,330 berada pada interval 0,20-0,399 dengan tingkat pengaruh rendah.

\section{Koefisien Determinasi}

$$
\begin{aligned}
\mathrm{D} & =\mathrm{r}^{2} \times 100 \% \\
& =0,109 \times 100 \% \\
& =10,9 \%
\end{aligned}
$$

Jadi terdapat korelasi antara LDR dan DER terhadap ROE yang besarnya pengaruh ini dapat dinyatakan secara kualitatif dengan pengujian koefisien determinasi lalu diperoleh nilai Koefisien Determinasi sebesar 10,9\%, artinya pengaruhLDR dan DER sangatlah kecil, sedangkan sisanya $89,1 \%$ dipengaruhi oleh faktor lainnamun tidak diteliti dalam penelitian ini misalnya faktor Non Performing Loan, Total Aset Turnover,Capital Adequacy Ratio dan lain-lain 


\section{Uji t (parsial)}

Uji $\mathrm{t}$ digunakan untuk mengetahui pengaruh antara tiap variabel bebas terhadap variabel terikat dan juga menjawab hipotesis dalam penelitian.

\begin{tabular}{|c|c|c|}
\hline \multicolumn{3}{|c|}{$\begin{array}{c}\text { Tabel } 9 \\
\text { Hasil Uji t } \\
\text { Coefficients }^{\mathrm{a}}\end{array}$} \\
\hline Model & $\mathrm{t}$ & Sig. \\
\hline & & , 186 \\
\hline LDR & ,921 & ,388 \\
\hline DER & ,407 & 696 \\
\hline
\end{tabular}

a. Dependent Variable: ROE

Berdasarkan hasil output SPSS

diatas maka diperoleh nilai uji $\mathrm{t}$ hitung untuk variabel LDR sebesar 0,921 dan nilai $\mathrm{t}$ hitung untuk variabel DER diperoleh sebesar 0,407.

Selanjutnya nilai t hitung tersebut dibandingkan dengannilai t tabel untuk $\mathrm{dk}=\mathrm{n}-2=10-2=8$ dan taraf kesalahan $5 \%$ maka diperoleh nilai $\mathrm{t}$ tabel sebesar 2,306, dengan ketentuan bila $\mathrm{t}$ hitung $<\mathrm{t}$ tabel maka $\mathrm{H}_{0}$ diterima dan $\mathrm{H}_{\mathrm{a}}$ ditolak begitu pula sebaliknya. Kemudian apabila nilai sig < 0,05 maka dinyatakan pengaruhnya signifikan ataupun sebaliknya.

Jadi nilai t hitung untuk variabel LDR (X1) sebesar 0,921 lebih kecil dari t tabel 2,306 $(0,921<2,306)$ dan nilai Sig $>0,05(0,388>0,05)$ artinya tidak signifikan maka $\mathbf{H}_{0}$ diterima dan $\mathbf{H}_{\mathbf{a}}$ ditolak atau dengan kata lain hipotesis nol yang berbunyi tidak terdapat pengaruh LDR terhadap ROE pada PT. Bank BNI Tbk secara parsial dapat diterima.

Kemudian nilai $\mathrm{t}$ hitung untuk variabel $\mathrm{DER}(\mathrm{X} 2)$ sebesar 0,407 lebih kecil dari $t$ tabel $2,306(0,407<2,306)$ dan nilai Sig $>0,05(0,696>0,05)$ artinya tidak signifikan maka $\mathbf{H}_{0}$ diterima dan $\mathbf{H}_{\mathbf{a}}$ ditolak atau dengan kata lain hipotesis nol yang berbunyi tidak tidak terdapat pengaruh DER terhadap ROE pada PT. Bank BNI Tbk secara parsial diterima.

\section{Uji F (Simultan)}

Uji F digunakan untuk mengetahui signifikansi pengaruh variabel bebas terhadap variabel terikat secara bersama-sama dan juga menjawab rumusan masalah serta hipotesis dalam penelitian.

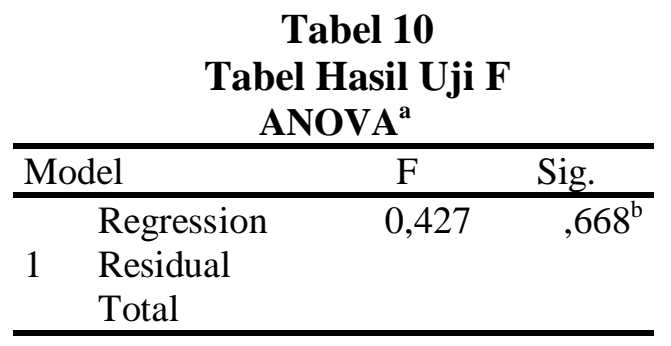

a. Dependent Variable: ROE

b. Predictors: (Constant), DER, LDR

Jadi diperoleh nilai uji $\mathrm{F}$ hitung $\left(F_{h}\right)$ sebesar 0,427 dan nilai ini selanjutnya dibandingkan dengan Ftabel $\left(\mathrm{F}_{\mathrm{t}}\right)$, dengan $\mathrm{dk}$ pembilang $=\mathrm{k}=2$ dan $\mathrm{dk}$ penyebut $=(\mathrm{n}-\mathrm{k}-1)=10-2-1=$ 7dan taraf kesalahan yang ditetapkan 5\%. Maka $F_{t}=4,74$. Dalam hal ini berlaku ketentuan, bila $F_{h}$ lebih besar dari $F_{t}\left(F_{h}>F_{t}\right)$ maka terdapat pengaruh secara simultan atau dengan kata lain $\mathbf{H}_{\mathbf{a}}$ diterima dan $\mathrm{H}_{0}$ ditolak begitu pula sebaliknya.

Dari hasil SPSS diatas ternyata $F_{h}<F_{t}$ atau $0,427<4,74$ maka dapat dinyatakan bahwa pengaruh secara simultan yang diuji adalah tidak berpengaruh dan tidak signifikan. Hal ini menjawab dan membuktikan hipotesis nol $\left(\mathrm{H}_{0}\right)$ pada hipotesis ketiga bahwa tidak terdapat pengaruh LDR dan DER terhadap ROE pada PT. Bank BNI Tbk secara simultan atau dengan kata lain $\mathrm{H}_{0}$ diterima dan $\mathrm{H}_{\mathrm{a}}$ ditolak.

\section{SIMPULAN}

Berdasarkan hasil analisis dan perhitungan diatas maka diperoleh LDR 
tidak berpengaruh terhadap ROE pada PT. Bank BNI Tbk secara parsial, dimana nilai thitung sebesar 0,921 lebih kecil dari nilai ttabel sebesar 2,306 $(0,921<2,306)$ dengan nilai signifikansi sebesar 0,388 lebih besar dari 0,05 $(0,388>0,05)$. Sedangkan DER tidak berpengaruh terhadap ROE pada PT. Bank BNI Tbk secara parsial, dimana nilai thitung sebesar 0,407 lebih kecil dari t tabel 2,306 $(0,407<2,306)$ dan nilai Signifikansi > $0,05 \quad(0,696>0,05)$. Selanjutnya LDR dan DER tidak berpengaruh terhadap ROE pada PT. Bank BNI Tbk secara simultan, dimana nilai Fhitung sebesar 0,427lebih kecil dari nilai Ftabel sebesar 4,74 $(0,427<4,74)$ dengan signifikansi> 0,05 $(0,668>0,05)$.

Disarankan pada PT. Bank BNI Tbk untuk melakukan evaluasi secara mendalam tentang Loan to Deposit Ratio (LDR) dan Debt to Equity Ratio (DER) karena dalam penelitian yang dilakukan dengan mengambil data selama 10 tahun terakhir ditemukan tidak berpengaruh terhadap ROE. Hal ini menunjukkan ada suatu masalah yang harus segera dipecahkan oleh para pemegang kebijakan di PT. Bank BNI Tbk untuk keberlangsungan dan perkembangan kedepannya agar menjadi lebih baik lagi. Sebab perusahaan yang baik haruslah memiliki kinerja dan rasio keuangan yang baik dan saling mempengaruhi satu sama lainnya.

Bagi peneliti selanjutnya yang akan meneliti tentang variabel yang sama diharapkan dapat lebih menyempurnakan penelitian ini, sehingga dapat dijadikan tambahan referensi dan wawasan ilmu pengetahuan khususnya tentang LDR, DER dan ROE di perbankan.

\section{DAFTAR PUSTAKA}

Akbar Ali, Shofar. 2015. Analisis Pengaruh Loan to Deposit Ratio (LDR) dan Debt To Equity Ratio (DER) Terhadap Kinerja Keuangan Return On Equity (ROE) Perusahaan Perbankan Di Indonesia Tahun 2009-2013. Fakultas Ekonomi dan Bisnis, Universitas Muhammadiyah Surakarta,4 (2) : 1-15.

Dendawijaya, Lukman. 2013. Manajemen Perbankan. Edisi Kedua, Cetakan Kedua. Ghalia Indonesia : Bogor.

Ghozali, Imam. 2011. Aplikasi Analisis Multivariate Dengan Program SPSS. Semarang : Badan Penerbit Universitas Diponegoro

Husnan, Suad, 2015.Dasar-Dasar Manajemen Keuangan, Edisi Ketujuh. Yogyakarta: UPP STIM YKPN.

Kasmir. 2016. Manajemen Perbankan. Edisi Pertama. Cetakan Kelima, PT. Raja Grafindo Persada : Jakarta.

Mudrajad Kuncoro, 2013. Metode Riset untuk Bisnis dan Ekonomi Edisi 4.Jakarta: Erlangga.

Monica.2019. Analisis Pengaruh CAR, NPL, NIM, BOPO, dan LDR Terhadap ROE Pada Bank Umum Swasta Nasional Devisa di Indonesia. Jurnal Manajemen Bisnis dan Kewirausahaan,3(3) : 1-11.

Munawar, Andri Helmi. 2018. Pengaruh Loan To Deposit Ratio dan Debt To Equity Ratio Terhadap Return On Asset Pada PT. Bank Mandiri (Persero) Tbk. Jurnal Ilmiah Adbis, 2(2) : 1-12.

Rosyadah, Faizatur. 2012. Pengaruh Struktur

Modal Terhadap Profitabilitas (Studi

Pada Perusahaan Real Estate and 
Property Yang Terdaftar Di Bursa

Efek

Indonesia (BEI) Periode 2009 2011).

Malang.

Sartono, Agus. 2014.Manajemen Keuangan:Teori dan Aplikasi. Edisi Keempat. Yogyakarta:BPFE.

Simorangkir. 2004. Pengantar Lembaga Keungan Bank dan Non Bank. Jakarta: Ghalia Indonesia.

Sugiyono, 2016. Metode Penelitian Pendidikan Pendekatan Kuantitatif,Kualitatif dan $R \& D$. Bandung : Alfabeta

Wahid, Sulaiman. 2004. AnalisisAnalisis Regresi Menggunakan SPSS. Yogyakarta : Andi.

Widowati. Sari Ayu. (2015). Pengaruh Rasio Keuangan Terhadap Profitabilitas Perbankan Di Indonesia. Jurnal Ilmu \& Riset Akuntansi Vol. 4 No. 6.

www.bni.co.id

www.idx.co.id 